\title{
Self-efficacy, academic anxiety, and self-regulated learning on mathematics achievement at vocational high school
}

\author{
Thamrin*, Ma'aruf Akbar, Burhanuddin Tola \\ \{thamrinabdkadir@yahoo.com\}
}

Universitas Negeri Jakarta, Indonesia ${ }^{123}$

\begin{abstract}
The aim of this research was to know the effect of self-efficacy, academic anxiety, and self-regulated learning towards mathematics achievement at vocational high school in Bogor, West Java Indonesia. The sample of this study was 360 students were determined by using multi-stage area cluster random sampling. The results show that; (1) there was a positive effect of self-efficacy towards mathematicsachievement, (2) there was a negative effect of academic anxiety towards mathematics achievement, (3) there was a positive effect of self-regulated learning towards mathematicsachievement, (4) there was a positive effect self-efficacy towards self-regulated learning, (5) there was a negative effect of academic anxiety towards self-regulated learning, and (6) there was a positive effect of self-efficacy towards academic anxiety. In conclusion, it can be proven that self-efficacy has a positive effect towards mathematics achievement, self-regulated learning, as well as academic anxiety. Furthermore, self-regulated learning has a positive effect towards Mathematic achievement, meanwhile, in contrast, academic anxiety has a negative effect in both learning achievement and self-regulated learning.
\end{abstract}

Keywords: Self-efficacy, academic anxiety, self-regulated learning, mathematics achievement.

\section{Introduction}

The successfully of learning process always generate to the behavior changes within students. The changes that may generated changes in cognitive, affective and psychomotor aspect. There are two components that need to be fulfilled to achieve a successfully of the learning process, (1) a well-planned learning activity and, (2) students that have self-efficacy, academic anxiety and learning independency by using libraries as learning source.

Mathematics is a mandatory subject that is taught from elementary to high school level. In achieving learning objectives in mathematics, the students are expected to be able to apply what they've got in the school in their daily life. Mathematics can improve one's ability in logical, analytical, systematical, critical and creative thinking as well as the skill to work together in a team. Therefore, mathematics education can be a tool to help prepare skillful human capital who can gain, manage and make use of information as needed. 
To improve the learning outcomes in mathematics, the teacher are pushed to work harder when in the reality achieving learning objectives are not necessarily easy. Based on author's observation and personal experiences as a mathematics teacher in a vocational high school in the Regency of Bogor, the problem with teaching mathematics are the students who are not enthusiastic and tend to be passive during learning activities. Minimum mastery criteria of grade XI for last 3 years is below the standard of 70 out of 100 .

A side from what has briefly described in this paper, other factors that affect students' performance in mathematics are internal factors such as: intelligence, motivation, interest, attention, learning habit, socio-economic condition, physical and psychological condition. psychological aspect will always provide help in achieving learning objectives. Some psychological factors that affect learning outcomes in mathematics are self-efficacy, academic anxiety and learning independency. These factorsare definitely possessed by students and therefore must be considered by teachers and educators.

Self-efficacyis a meta cognitive process that requires students to explore their own thought processes so as to evaluate the results of their actions and plan alternative pathways to success. Successful learners organize their work, set goals, seek help when needed, use effective work strategies, and manage their time [1]. While [2] defined self-efficacy is aperson's belief that she is capable of performing a particular task successfully [3] explained that self-efficacy as person's assessment on their ability to organize their learning to achieve the goal of the edacation process.

Described the anxiety as a not comfortable sensation, afraid sensation, crankiness, nervous, and exhaustion [4]. While Lazarus and Averill defined anxiety as "an emotion based on the appraisal of threat, an appraisalwhich entails symbolic, anticipatory, and uncertain elements [5]. Anxiety results when cognitive systems nolonger enable a person to relate meaningfully to the world". Stated that academic anxiety as nervous and afraid sensation on something that will be happened [6]. It can disturb the activities in academic situation.

In general, students can be described as self-regulated to thedegree that they are metacognitively,' motivationally, andbehaviorally active participants in their own learning process [7]. Then, Boekaerts \& Niemivirta described that self-regulated is defined as thoughts, feelings, actions, and behaviors generated bylearners to systematically and intentionally attain their goals [8]. Defined self-regulated is individuals who are metacognitively, motivationally, and behaviorally active participants in their own learning process [9]. Self-regulated also can be defined as an activeprocess in which students establish the objectives leading theirlearning, trying to monitor, regulate and control their cognitions,motivation and behaviour in order to achieve them [10].

The previous research by Tanta examines about the effects of self-efficacy, self-regulated learning, and habits of mind towards Biology achievement at senior high school in Jayapura Papua. The study shows that 1) self efficacy has a positive impact towards students self regulated learning, and 2) self-efficacy has a positive impact towards Biology achievements. The other research by HannyIsthifa examines about the impact of self-efficacy towards self-regulated learning of UIN Jakarta students. The result shows that 1) self-efficacy has a positive impact as regard to self-regulated learning, and 2) academic anxiety has a negatif impact towards self-regulated learning. Amalia Putri investigates about the relationship between academic anxiety and self-regulated learning towards student of International Standardize School Pioneer in SMA Negeri 3. It shows that there was a negatif relation between academic anxiety and self-regulated learning. While Sanitiara, Elda Nazriati, and Firdaus had conducted a research that focused on the relationship between academic anxiety 
and self-control towards Medicine student in University of Riau. The result founds that there was not a relation between academic anxiety and self-control learning.

Based on introduction built above, this research has been done to examine: (1) the effects of self-efficacy toward learning outcomes in mathematics, (2) negative direct effect of academic anxiety toward learning outcomes in mathematics, (3) direct effect of learning independency toward learning outcomes in mathematics, (4) direct effects of self-efficacy toward learning independency, (5) negativedirect effect of academic anxiety toward learning independency and (6) positive direct effects of self-efficacy toward academic anxiety.

\section{Method}

Research method that is used is causal survey by using path analysis approach. This research was held on April to July of 2016/2017 in the Regency of Bogor, West Java. The research data set can be accessed in osf.io Open Science Framework. Target populations are 12.397 students in private vocational high schools that study marketing. The accessible populations are grade XI students in business management program. Data analysis technique used are: statistics descriptive analysis, inferential statistics, multivariate statistics using path analysis approach. Analysis tools that was used are SPSS 20 and Structural Equation Modeling (SEM) through LISREL 8.80 Full Version program.

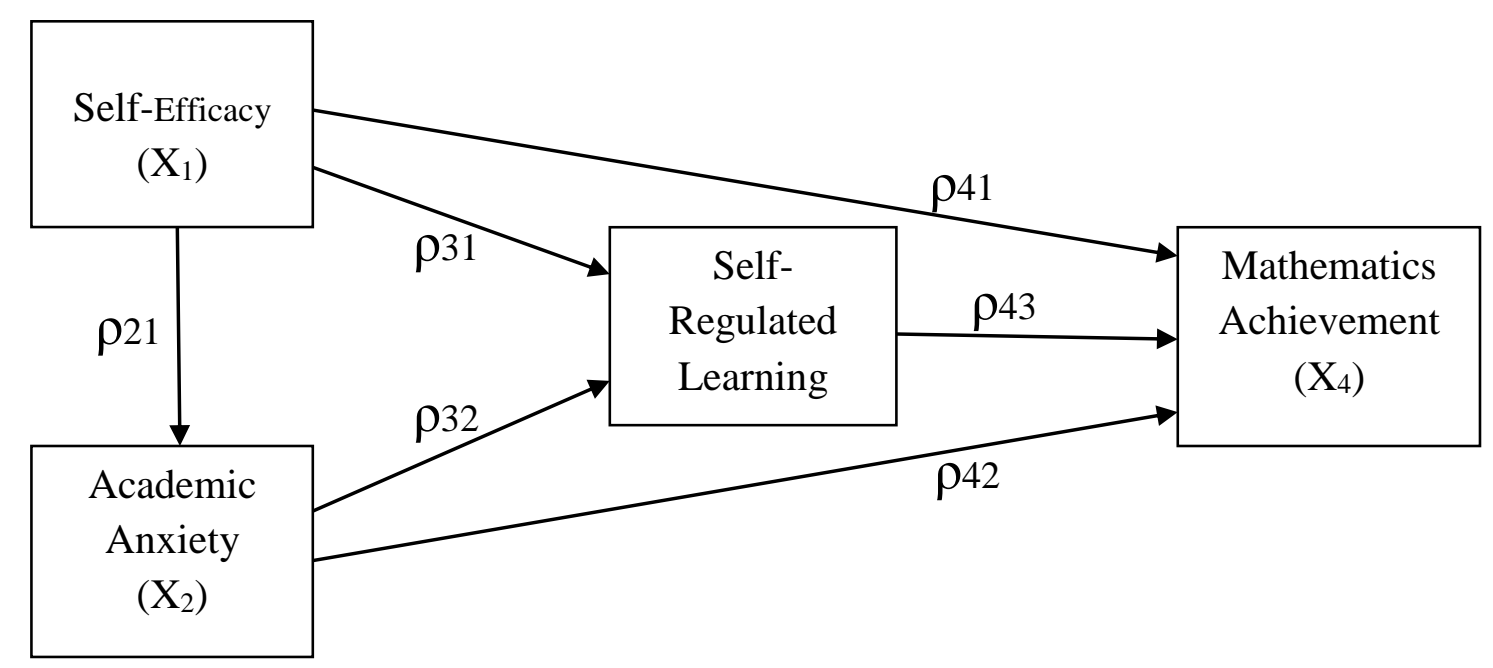

Figure 1. Research Design

\section{Results}

Objective result of this research are: $(1)$ tstatistics $=3,048>$ ttable $(0,05: 360)=1,65$, then $\mathrm{H} 0$ is rejected, therefore path coefficient $\beta 41=0,188$ is significant. This fact implies that self-efficacy has direct positive effect on learning outcomes. (2) tstatistics $=4,125>$ ttable $(0,05: 360)=1,65$, then H0is rejected, therefore path coefficient $\beta 42=-0,232$ is significant. 
This implies that academic anxiety has direct negatif effects on learning outcomes. (3) tstatistics $=2,734>$ ttable $(0,05: 360)=1,65$, then $\mathrm{H} 0$ is rejected, therefore path coefficient $\beta 43$ $=0,153$ is significant. This implies that learning independency has direct positive effects on learning outcomes. (4) tstatistics $=8,749>$ ttable $(0,05: 360)=1,65$, then H0is rejected, therefore path coefficient $\beta 31=0,463$ is significant. This fact implies that self-efficacy has positive direct effects on learning independency. (5) tstatistics $=1,888>$ ttable $(0,05: 360)=$ 1,65 , then H0is rejected, therefore path coefficient $\beta 32=-0,100$ is significant. This fact implies that academic anxiety has direct negativeeffects on learning independency. (6) tstatistics $=8,995>$ ttable $(0,05: 360)=1,65$, then H0is rejected so the path coefficient $\beta 21=$ 0,429 is significant. This implies that self-efficacy has direct effects on academic anxiety.

\section{Discussions}

\subsection{Self-Efficacy Has Direct Positive Effects on Academic Anxiety}

This research found that self-efficacy has direct positive effect on academic anxiety. Path coefficient of self-efficacy on academic anxiety $\left(\beta_{21}\right)$ is 0,429 .

Bandura explained that self-efficacy plays important roles in causing academic anxiety. Self-efficacy is one's firm belief about his capability to handle problems and to win situations in order to have positive results. The root of academic anxiety lies with poor efficacy. Previous research show that there is significant relation between self-efficacy and academic anxiety. The better self-efficacy in oneself, the less academic anxiety he might has, and vice versa.

\subsection{Self-Efficacy Has Direct Positive Effects on Learning Independency}

This research found that self-efficacy has direct positive effects on learning independency. This implies that independency level of student in learning can be explained by self-efficacy. Path coefficient of self-efficacy on learning independency $\left(\beta_{31}\right)$ is 0,463 .

Self-efficacy can affect students in picking tasks, effort, diligence and performance. Students who have high level of self-efficacy will have confidence in finishing tasks, figuring answers and achieving goals. Besides, students with various skills tend to be more ready to participate and work hard in difficult situation.

\subsection{Academic Anxiety Has NegativeDirect Effects on Learning Independency}

This research shows that academic anxiety has direct negatif effects on learning independency. It means that student's independecy level can be explained by academic anxiety. coefficient path of academic anxiety on learning independency $\left(\beta_{32}\right)_{\text {is }} 0,-0,100$.

Academic anxiety brings negativeconsequences toward learning independency. It affects cognitive aspects which will then manifested into one's behaviour during learning activity. Learning strategy is a significant part of learning independency.

Amalia Putri Pratiwi examined relation of academic anxiety and learning independency on students in Public Senior High School (SMA Negeri) 3 Surakarta. Her findings including 
significant negativerelation between academic anxiety and learning independency. This was indicated by the correlation coefficient -0,294. Significant relation between these two indicated that high level of academic anxiety will be followed by low level of learning independency and vise verse.

\subsection{Self-Efficacy Has Direct Positive Effects on Learning outcomes in Mathematics.}

This research found that self-efficacy has direct positive effects on learning outcomesin Mathematics. It means that learning result can be explained with self-efficacy. Path coefficient of self-efficacy toward learning results $\left(\beta_{41}\right)$ is 0,188 .

According to Fred C Lunenburg, Self-efficacy is one's firm belief about his capability to handle problems and to win situations in order to get positive results. Efficacy can help students in deciding learning strategies.

\subsection{Academic Anxiety Has Direct NegativeEffect on Learning Results in Mathematics}

This research found that academic anxiety has direct negativeeffects on student's learning results in mathematics. Path coefficient of academic anxiety toward learning results $\left(\beta_{42}\right)$ is $-0,232$

Academic anxiety is one factor that affects motivation. An individual with anxiety will have challenges in doing his tasks or achieving his goals. Academic anxiety is one kind of anxiety that comes from academic setting such as from teachers or the subjects. Several researchers have explained that there is relation between learning accomplishment and anxiety. Students with high level of anxiety tend to get poor results in his study.

\subsection{Learning Independency Has Direct Positive Effects on Learning Result in Mathematics}

This research shows that learning independency has positive direct effects on learning results in mathematics. Path coefficient of learning independency toward learning results in Mathematics $\left(\beta_{43}\right)$ is 0,153 .

According to Zimmerman as quoted by Chen, learning independency is student's participation level that actively involving meta-cognitive aspect as well as motivation and behaviour during learning activity. Learning independency is a basic requirement for students to decide action and attitude toward learning process. It also encourages students to be more initiative and creative and in turn makes them more productive.

\section{Conclussion}

Based on this research, it can be concluded that: (1) self-efficacy has direct positive effects on learning outcomes in mathematics, (2) academic anxiety has direct negatif effects on learning results in mathematics, (3) learning independency has direct positive effects on learning results in mathematics, (4) self-efficacy has direct positive effects on learning 
independency, (5) Academic anxiety has direct negatif effects on learning independency and (6) self-efficacy has direct positive effects on academic anxiety.

\section{References}

[1] E. L. Usher and F. Pajares, "Self-efficacy for self-regulated learning: A validation study," Educational and Psychological Measurement, vol. 68, pp. 443-463, 2008.

[2] F. C. Lunenburg, "Self-efficacy in the workplace: Implications for motivation and performance," International journal of management, business, and administration, vol. 14, pp. 1-6, 2011.

[3] D. H. Schunk and F. Pajares, "Self-efficacy theory," Handbook of motivation at school, pp. 35$53,2009$.

[4] S. N. Elliott and J. F. Travers, Educational psychology: Effective teaching, effective learning: Brown \& Benchmark Madison, WI, 1996.

[5] M. A. Siddiqui and A. U. Rehman, "An interactional study of academic anxiety in relation to socio-economic status, gender and school type among secondary school students," International Journal of Educational Research and Technology IJERT, vol. 5, pp. 74-79, 2014.

[6] T. Urdan and F. Pajares, Selfefficacy beliefs of adolescents: IAP, 2006.

[7] B. J. Zimmerman, "A social cognitive view of self-regulated academic learning," Journal of educational psychology, vol. 81, p. 329, 1989.

[8] Y. Huh and C. M. Reigeluth, "Self-Regulated Learning: The Continuous-Change Conceptual Framework and a Vision of New Paradigm, Technology System, and Pedagogical Support," Journal of Educational Technology Systems, vol. 46, pp. 191-214, 2017.

[9] B. Abar and E. Loken, "Self-regulated learning and self-directed study in a pre-college sample," Learning and individual differences, vol. 20, pp. 25-29, 2010.

[10] A. Valle Arias, et al., "Self-regulated profiles and academic achievement," Psicothema, 2008. 